\title{
Ni con goma
}

"If you go up two floors, no one in this building even knows what the REPUVE is. They know that we're here on this floor. But they don't know what the program is ..."

"Until they have their car stolen. Then they know what it is." -Lucas Espinoza and Daniela Flores, REPUVE administrators

\section{I TEN THOUSAND CALDERÓNS}

On April ıо, 20ıо, an important deadline loomed for mobile telephone users in Mexico. By this date, cell users needed to register their phone lines with the government's National Registry of Mobile Telephone Users (RENAUT) or risk termination of service. ${ }^{\mathrm{I}}$ Users could register in one of two ways: by sending a text message to the number 2877 with the word "ALTA" (Spanish for "subscribe"), together with their name and date of birth or their Unique Population Registry Code (CURP); or by going to a service provider to have their data recorded. ${ }^{2}$ Registrations at service centers would also record user fingerprints as a security measure.

The deadline did not pass without controversy, however. Public reaction to the RENAUT was highly critical. The registry was said to violate the privacy granted by Article I 6 of the Constitution, which sets out people's right to not be disturbed in their home, property, or documents except upon a court order. ${ }^{3}$ And various lawsuits challenged the legality of the registry. ${ }^{4}$ The critical reception extended to service providers as well. They refused to comply with the RENAUT's requirements to collect biometric data. And they vacillated on the question of suspending service to subscribers who did not register their phone lines. Movistar, which controls 20 percent of Mexico's cellular market, announced that it would not suspend service; Telcel, which holds majority market share 
and is owned by sometimes "world's richest person" Carlos Slim, stated that it would suspend lines but allow continued text service.

Fittingly, given the ethereal substance of mobile communications, the controversy extended into the digital realm. In the days and weeks before the deadline, the Twitter page \#RENAUT exploded with messages critical of the program:

For my part (and I believe many others), \#RENAUT is not the solution and I do not agree with it, let's say \#NOalReanut [sic] -> http://ow.ly/ıoez Y

I say \#No to Big Brother! Campaign against dystopia. http://www. noalgranhermano.org/ \#acta \#renaut \#mexico

Remember the scandal about the national registry of autos? Do you trust registering your cellular phone? \#RENAUT \#mx

"Possible FAIL for \#RENAUT . . we can register ourselves with fake info and more than once ... hahaha!! http://www.milenio.com/node/403397 Give it a RT

They Can Take Away Our Cell Phone Numbers But They Cant Take Away Our Freeeeeeeeeedoooooooooom \#renaut http://tinyurl.com/yzvn 585" [original in English]

Did you know the \#RENAUT plans to include your fingerprints in a second stage? Check out: http://bit.ly/ajTyTW \#BigBrotherFail

Twitter messages such as these not only conveyed people's antipathy toward the telephone registry but also included key details about its operation that readers might not already know. The registry would include fingerprints. And more importantly, one could register multiple times using false data.

Various webpages offered additional information on the registry's operation. One blog, Trucos para evadir RENAUT (Tricks for evading RENAUT), featured an image of a naked foot with its sole facing the reader and its middle toe extended in simulation of a middle finger. It gave readers strategies for duping the registry, for example, what the blog called the "zombie" technique: "We search for deceased Mexicans on the Internet or in a newspaper. We copy the data of the deceased and register them. That way we have a live phone, but with calls from the great beyond." Another option was the "chameleon," targeting social networks such as Facebook and $\mathrm{HI}_{5}$ : "We search, in whatever network, user profiles that display names, dates of birth, and places of residence, preferably those with advertising attached to them, since they are usually already registered with their CURP." The post goes on, "There are also various social networks of professionals (accountants, lawyers, engineers, etc.) where 
users display their full name and date of birth. Also, we can casually add friends to Facebook or $\mathrm{HI}_{5}$ to learn their data. Once we have recorded the data, we can go the [federal government's] CURP Web portal and fill out the profile data for the users, hit click, and BINGO! it shows you their CURP, which we will send to RENAUT, who accepts it gladly. This is a bit tedious, but completely reliable. Io०\% tested. This is how I registered." ${ }^{6}$

The "chameleon" strategy highlights an interesting characteristic of Mexico's Unique Population Registry Code. The algorithm that generates the CURP is publicly available, making it possible to calculate other people's codes, so long as their full name and date of birth are known. On this basis, those critical of the RENAUT pushed the envelope further, detailing how a simple Wikipedia entry for someone like President Felipe Calderón could be used, in combination with the National Population Registry's CURP portal, to determine his CURP and register one's phone line with it.'

When the April deadline passed, 70 percent of the 83,500,000 mobile lines in Mexico were registered with the RENAUT. This left 25,202,935 lines at risk of disconnection. However, the digital campaign against the RENAUT left its mark. Newspapers reported that upward of 50,000 of the millions of telephone numbers registered were fictitious, with I०,००० registrations made in the name of President Felipe Calderón. ${ }^{8}$

But the National Registry of Mobile Telephone Users was not alone in its difficulties. The Citizen Identity Card (CEDI) was mired in its own problems. The identity card had been announced by Calderón in July 2009. Already by August 2009, the newspaper La Jornada published opinions of officials from the Federal Electoral Institute (IFE) who criticized the CEDI on the basis that Mexicans would confuse it with their voter card. The voter card, according to the officials, had served as the de facto form of national identity for the last two decades and the government had invested $\$ 4$ billion in it. Alberto Alonso y Coria, executive director of the Federal Electoral Registry, explained that the voter registry contained the biometric data of seventy-eight million people of voting age and that the voter card should "survive and remain under whichever scheme, because it is an instrument that not only has a broad social acceptance, but also the legal capacity to identity Mexican citizens and provide security in the most important event for the IFE, voting. The ID allows us to guarantee that only those who have the right to vote do so and that they only do so once." ${ }^{9}$ In the eyes of the IFE, the Citizen Identity Card was not only a waste of taxpayer money but also a threat to the integrity of democratic elections in Mexico, a right only recently won. And as one of the most respected institutions in Mexico, 
after the Catholic Church and the military, ${ }^{\text {Io }}$ the IFE's opposition to the CEDI helped engender a wider opposition to the card and placed the fate of the program in doubt.

The Public Registry of Vehicles (REPUVE), meanwhile, was encountering its own complications. Unlike the other two programs, these were born not of notoriety but of a lack of familiarity altogether. When I visited Mexico City in summer 2010 to collect data on the REPUVE, I learned that no one in my immediate circle of friends and acquaintances had heard of the program. Indeed, no one I spoke to around the city knew of it, despite the pomp and circumstance accompanying its launch the previous summer. Invariably, in their effort to be polite to a misguided gringo, people explained that what I was describing sounded much like the mobile telephone registry, which was regularly in the news that spring. The defeños' (residents of Mexico City) ignorance of the automobile registry was understandable. Although the program aimed to register, inspect, and regulate the nearly twenty-five million vehicles circulating in the country by 20I 2, "I only a handful of Mexico's thirty-two states (San Luis Potosí, Veracruz, Baja California Sur, Colima, Sonora, and Zacatecas) were applying radio-frequency identification (RFID) tags to vehicles in summer 2010, thus leaving the future of the registry in considerable doubt.

These vignettes demonstrate that if Mexico's mobile telephone registry, identity card, and automobile registry evidence a distinct mode of governmentality, "making thing stick" is more easily done in theory than in practice. State strategies for gaining new holds on communications, personal identification, and mobility meet with multiple obstacles. People refuse to comply with measures they deem invasive. Companies balk at the financial costs associated with new programs. And politicians, public officials, and state governments oppose these efforts for political gain and to protect their own domains of power. As a result, the viability of these programs is left in question. Thus, while the basic logic of the RENAUT, CEDI, and REPUVE can be described as probesion, the diverse points of resistance that the programs encounter give the impression that "nothing works," a sense captured by the Spanish phrase ni con goma, which is used when things "do not fit" or "go together" but literally means "not even with glue," an apt phrase to describe the failings of programs intended to "make things stick."

This chapter concentrates on the resistance that state surveillance in Mexico engenders. While the term "resistance" might immediately bring to mind concerned individuals organizing themselves to oppose 
the government, the stories that make up this chapter offer a more expansive view of defiance in sociolegal contexts. Over the past three decades, scholars have come to conceive of resistance in terms of the everyday "weapons of the weak" ${ }^{\mathrm{I} 2}$ that ordinary people draw on to oppose the "common place of law" ${ }^{\mathrm{I} 3}$ in their lives. The uneven histories of the RENAUT, CEDI and REPUVE, however, demonstrate that major points of resistance to state projects derive from other sources as well, including political and bureaucratic structures formed over the course of modern history, cultural formations residing at the core of national histories, and technological and design elements embedded in monitoring programs. As the state looks to gain a greater hold over collective agencies in society that are distributed across a diverse collection of actors, institutions, and material arrangements, it encounters resistance all along that distribution. To understand the power, or lack thereof, of surveillance technologies in contemporary society, then, one must not only consider their design, nor just individuals' reactions to them, but the range of resistance they encounter.

\subsection{RESISTANCE IN THEORY}

Resistance is part and parcel of any effort to exercise control. Michel Foucault made this point bluntly with his oft-quoted dictum that "where there is power, there is resistance." "It It is James Scott, however, who provides the definitive treatment of resistance in his influential work Weapons of the Weak. Based on research with Malay peasants, Scott claims that the weak do not counter authority through the "peasant rebellions," "peasant revolutions," or other forms of organized resistance that have usually captured the imagination of scholars. Rather, they do so through "everyday forms of peasant resistance," which consist of "foot dragging, dissimulation, false compliance, pilfering, feigned ignorance, slander, arson, sabotage, and so forth." In contrast to organized resistance, such as strikes, marches, or political campaigns, these mundane forms of resistance "require little or no coordination or planning; they often represent a form of individual self-help; and they typically avoid any direct symbolic confrontation with authority or with elite norms." ${ }^{\mathrm{I}}$

This is not to say that resistance cannot take organized forms. Although Scott does not engage it directly, the literature on social movements and collective action describes tools that subjects can employ, in addition to the "weapons of the weak," against those in authority. 
Whether arising from the rational choices of participants ${ }^{16}$ and mobilization of resources by organizers, ${ }^{17}$ political opportunities at a given historical moment, "the "historicity" of contemporary societies, "the construction and maintenance of collective identity, ${ }^{20}$ the strategic framing strategies of organizers to the broader public, ${ }^{2 \mathrm{I}}$ or the emotions and meanings imbued in issues and events, ${ }^{22}$ collective action is able to produce the force necessary to both resist the debilitating effects of power and remake the social landscape by effecting political change, ${ }^{23}$ legislative action, ${ }^{24}$ or-even when failing to achieve stated goals-raising public consciousness around key issues. ${ }^{25}$

But Weapons of the Weak highlights the effects that seemingly innocuous "everyday forms of resistance," devoid of the lofty goals of collective action, can have. "When such acts are rare and isolated, they are of little interest," Scott explains, given their inability to affect the operations of hierarchical relations in society. "But when they become a consistent pattern (even though uncoordinated, let alone organized) we are dealing with resistance," which counts as "any act(s) by member(s) of a subordinate class that is or are intended either to mitigate or deny claims (for example, rents, taxes, prestige) made on that class by superordinate classes (for example, landlords, large farmers, the state) or to advance its own claims (for example, work, charity, respect) vis-à-vis those subordinate classes." "The intrinsic nature and, in one sense, the 'beauty' of much peasant resistance," he adds, "is that it often confers immediate and concrete advantages, while at the same time denying resources to the appropriating classes, and that it requires little or no manifest organization." ${ }^{27}$

The withholding of resources to the appropriating classes is vital for understanding the true force behind the "weapons of the weak." To make the point, Scott offers the example of peasant desertions from the Russian Army in I9I7 during the height of the First World War. ${ }^{28}$ The desertions were not motivated by high-minded aspirations to topple the czarist regime and fight for a progressive political agenda. The poor souls who found themselves conscripted into the Imperial Russian Army simply wanted to return home to care for their families. But these self-interested acts, coalescing into a wave of desertions, led to the collapse of the czar's main institution of repression and hastened the fall of Nicholas II and the Russian imperial order.

Scott's work on peasant resistance has profoundly influenced the social sciences. In the case of sociolegal research, this perspective helped pave the way for understanding the "common place of law." In this view, the law is not a mere tool of authority that instantaneously 
endows those possessing it with a mystical power to dictate relations in society. It is instead a process that can provide the subaltern unanticipated opportunities to resist and counter those in positions of authority. This is so whether one speaks of a Filipino peasant in the US territory of Hawai'i, whose refusal to have his stigmata treated disrupts the formation of identities central to the exercise of power in the occupied land, or of the feminist movement's activism to change domestic violence law to protect women from gender violence. ${ }^{29}$ In the "common place of law," people can oppose authority through "resistance against law," which means refusing to comply with its dictates; "resistance by means of law," which is using the legal system to challenge authority and privilege; and "resistance which redefines the meaning of law," by adopting the law's language and legitimacy to challenge established notions of justice and the social world. ${ }^{3}$

This literature on resistance provides a good starting point for understanding the difficulties experienced by the National Registry of Mobile Telephone Users, the Citizen Identity Card, and the Public Registry of Vehicles. And the next sections borrow from it to describe the positions that the public and business community assumed against the surveillance programs. However, the obstacles faced by the federal government in implementing its security programs extend beyond these traditional sources of resistance. The surveillance technologies in Mexico's War on Crime have confronted four distinct types of challenges: the concerns of citizens, the misgivings of the business community, the composition of the state and interplay of political interests within it, and technical constraints. Because each is meaningful to the outcomes experienced by the Calderón administration in attempting to reform the state's security apparatus, the following review encourages a broader understanding of resistance in sociopolitical contexts.

\subsection{THE OPPOSITION OF ORDINARY MEXICANS: PRIVACY, SECURITY, AND DISTRUST}

The digital campaign against the RENAUT reveals that many people in Mexico took a clear position "against the law." These individuals were critical of the law. And they sought to sabotage its operation. But what would bring ordinary people in Mexico to stand against the RENAUT? This section examines three interrelated sources of uneasiness: concerns over privacy, insecurity about the security of the state, and mistrust of the state forged over time. 


\subsection{Privacy Concerns}

Over spring and summer 20II, I distributed a survey about the RENAUT, CEDI, and REPUVE and security in Mexico to ninetyeight individuals from upper-middle and working-class neighborhoods in Mexico City and rural Zacatecas. The survey briefly described the programs and asked respondents to answer a series of questions about them, including "Do you support this program?" and "Why?" When responding to the "Why?" question, respondents were prompted to provide a short answer.

In the case of the RENAUT, 52 of 97 (53.6 percent) respondents answered "No" to the question of supporting the program. The most common reason identified in their short answers had to do with "privacy":

To me, [this program] should not have been implemented because it controls people and violates privacy.

I don't agree [with the program], there is already no privacy. They take away our privacy but you can't do anything about it

because it's mandatory.

Thus, people in Mexico, like people in other countries asked about their opinions on government surveillance, ${ }^{3 \mathrm{I}}$ felt that having to register their phone lines would result in a loss of privacy.

\subsubsection{Security Insecurities}

Interestingly, however, privacy concerns in Mexico involve more than unease about what the government might know about you. As frequently, people expressed the following concerns:

Personal data are used for other purposes.

I believe that the information is sold to criminals.

There is so much corruption and you don't know who to trust.

It [the registry] won't help; if the data are used, they'll be used by criminals inside of the program.

Many times they sell information to other companies.

As these statements reveal, while Mexicans are concerned about the government violating their privacy, they are as concerned about criminal elements or other third parties gaining access to their data. In other 
words, they are not so much worried about the "right to be let alone," as US Supreme Court justice Louis Brandeis famously described the right to privacy, as they are about the security of their personal data.

There is a touch of irony to Mexicans' concerns about data security, since the telephone registry is designed to bolster security. More importantly, these concerns increased skepticism about the program, which dampened the number of people registering their phones ahead of the April Iо, 2010, deadline. But these doubts were not exclusive to the RENAUT. In the case of the Citizen Identity Card, this apprehension about privacy and, more specifically, data security was repeated. Asked to give their opinions in support or opposition of the CEDI, 52 of 97 ( 53.6 percent) again responded "No." As to "why," those surveyed noted, "It's bad that now the government wants to keep us under watch," "We already have IFE, why do we need more?" and "Because they will always be checking in on us." But data security again was uppermost in their minds: "There's no guarantee that my data will be in good hands," "Because I no longer trust the president," and "I'm not sure it's legitimate; it doesn't give me confidence."

Believing that the government works hand in hand with criminal elements or is willing to sell citizens' private data to the highest bidder might sound overly suspicious. But it is worth remembering that these opinions harken back to historical events in Mexico that remain present in people's memory. The Twitter user at the beginning of the chapter who remarked, "Remember the scandal about the national registry of autos? Do you trust registering your cellular phone?" provides a prime example of this. The registry the user references is the National Registry of Vehicles (RENAVE), the notorious for-profit program operated by Ricardo Cavallo, the Argentine war criminal, who did indeed use the registry's databases to target vehicles to steal. In this case, the criminal was very much a part of the government. Following that sordid tale, in 2002, all of the data of sixty million Mexican voters contained in the Federal Electoral Registry and managed by the Federal Electoral Institute, the main opponent to the new identity card, was sold by the Mexican company Soluciones Mercadologías, which had been contracted to manage the database, to the US company Choice Point. ${ }^{32}$ Choice Point in turn resold the data, for the price of $\$$ I million per year, to the US federal government, whose Border Patrol used it to identify Mexican migrants crossing the Mexican-US border. Thus, data entrusted to the government has been sold to third parties and used against Mexican citizens before. These stories remain present in the 
popular imagination of Mexicans and are a ready well of mistrust when they encounter programs such as the mobile phone registry, national identity card, or automobile registry.

Politicians and those working with the programs openly acknowledged the challenge these ghosts of Mexico's administrative past posed in the present. As Mexican senator Miguel Angel Chico Herrera expressed when discussing the CEDI in a 20I I newspaper interview, "The population has lost trust in authorities and it has to be said openly that these identity documents could end up on the black market, as happened with other documents ... the registry of vehicles or the voter roll that the IFE has, and so many other documents, identifications, or lists of citizens that have appeared on the black market." ${ }^{33}$ Diego Avila, meanwhile, a technician working at the REPUVE site in Zacatecas that I visited, noted much the same. "There are 20 percent of the people that simply are not going to come, they're not going to come [to register]. Maybe they have bad information. They think that this is insecure, that we work for criminals, like RENAVE. RENAVE was a bad program that is distorting the REPUVE, because people think that it's the same story." This left those responsible for implementing the program, such as Samuel Gallo, an official in the REPUVE's State and Federal Operations Implementation Directorate, in a position where they had to, as he explained it, "combat the history of RENAVE."

\subsubsection{Government Mistrust}

At the heart of Mexicans' historical memory and their critical comments about the three security programs is a mistrust of government, a view of the government as corrupt, illegitimate, and/or ineffective. At times, these views are expressed explicitly. In certain media outlets, for instance, the Citizen Identity Card has been deemed of dubious legitimacy because the amendment to the Population Law calling for its creation "was passed in I990 . . as a mere expression of the will of the head of the executive branch"-Carlos Salinas-who has gone down as the most unpopular leader in modern Mexican history after Porfirio Díaz. ${ }^{34}$ Implemented before Mexican democracy returned, the CEDI is seen to lack the weight of the law.

Similarly, on blogs and opinion pages, people doubted that the government would ever be able to enforce the sanctions associated with noncompliance. Commenting on the RENAUT, for example, Ernesto Villanueva, a law professor at the National Autonomous University of 
Mexico specializing in information rights, opined that "it's going to be impossible to eliminate [people's cellular] service or impose a sanction on $40 \%$ or $60 \%$ of cellular users because they will never have a cell phone in their name. Please! We live in Mexico. If the most basic elements of public security cannot be guaranteed, how are they going to selectively apply the law to those Mexicans and the national cellular industry?" ${ }^{55}$ Because the state is unable to control crime in the first place, it is hard for some observers to believe that the state will be capable of policing something as sophisticated as mobile technology or of contending with the influence of cell service providers.

The historical memory of Mexicans thus bears on their experiences and expectations of surveillance programs in the present. As James Scott mentions in describing the roots of resistance beyond self-interest, many forms of resistance

may be individual actions, but this is not to say that they are uncoordinated. . . It is, for example, no exaggeration to say that much of the folk culture of the peasant "little tradition" amounts to a legitimation, or even a celebration, of precisely the kinds of evasive and cunning forms of resistance I have examined.... In this and in other ways (for example, tales of bandits, peasant heroes, religious myths) the peasant subculture helps to underwrite dissimulation, poaching, theft, tax evasion, avoidance of conscription, and so on. While folk culture is not coordination in the formal sense, it often achieves a "climate of opinion" which, in other more institutionalized societies, would require a public relations campaign. ${ }^{36}$

In Mexico, the bizarre stories surrounding previous efforts to register people and things enter into popular culture and serve as touchstones that work against similar programs in the present, placing many Mexicans in a position "against the law" of prohesion.

\subsection{THE CONCERNS OF COMPANIES: COSTS, CORRUPTION, AND CONFUSION}

Ordinary Mexicans-whose mobile phones, multiple forms of identification, and automobiles are the focus of the surveillance programs-were not the only ones opposing the programs. Companies and businesses responsible for the manufacture, sales, and service of the technological artifacts at the heart of mobile telephony and automobility also resisted the move toward prohesion. As noted at the start of the chapter, cellular service providers varied in their support of the RENAUT. Movistar publicly opposed the program, stating that it would neither provide 
users' data, collect biometrics, nor cut services to those who did not sign up. Automobile producers and importers also expressed reservations about the REPUVE. And like the survey respondents, history loomed large.

In an interview with Tomás Ayala and Vicente Bautista of the Procedures and Citizenry Directorate at the REPUVE, Bautista explained that the RENAVE was casting a shadow over how companies were approaching the REPUVE. "The companies are providing information, let's call it confidential, about the company as well as the dealers and the purchaser," he explained. "The management of this information is a concern because, yes, there was a problem before. The system failed. Who knows what happened with the information that was there. . . So obviously, the industry asked us, "Whose hands are we putting this information in?' . . . They didn't accept the REPUVE blindly." But if companies shared ordinary Mexicans' concerns about privacy and data security, the main obstacles for the business sector in general were the implied costs of complying with the new surveillance programs, the corruption perceived in government operations, and the confusion surrounding the programs.

\subsection{Business Costs}

Unsurprisingly, perhaps, the operational costs of complying with the new surveillance programs figured most centrally in many companies' thinking. In publicizing their reservations about the RENAUT, the mobile telephone industry estimated that complying with the registry law would cost it \$IOo million. ${ }^{37}$ Such costs were also a primary sticking point for the automobile industry concerning the REPUVE. Fernando Orozco, a representative with the Velocity Motor Corporation (VMC), a major car manufacturer in Mexico, explained to me, "The truth is that we as a car producer never wanted the REPUVE. Why? Because it generates a cost for us. It generates a very high cost that cannot be reflected in the [price of the] vehicle. It's a severe operational expense." Agustín Sandoval, a representative from Sucaro, a car manufacturer importing vehicles to Mexico from Asia, sounded a similar note of critique when I interviewed him: "The responsibility [for tagging vehicles] is ours, not the state or city. Now, politically speaking, we didn't want to accept the responsibility for adhering the chip. We said, 'Let the government do it!,' 'Put up modules [for chips] where plates are given out!,' 'Let the government do it!' Why us?" 
The operational and administrative costs are clearer to see the closer one gets to the production line. VMC provided me a tour of its plant outside Mexico City. Company representatives noted with clear pride the efficiency of their production process, explaining that a vehicle comes off the production line every eighteen seconds. It was precisely this precision that the REPUVE tags threatened. "We cannot stop the flow of vehicles," Orozco explained as we toured the facility. "So we had to adapt ourselves to have the flow be the same, so that it would be continuous and would not stop, whether we're talking about a sedan or a pickup." But at the same time, the REPUVE law required car makers to ensure that cars coming off the line had a REPUVE sticker on them. “A vehicle doesn't leave the plant if it doesn't go through the REPUVE. If a vehicle doesn't have a sticker, or a registration with REPUVE, we cannot sell it," Orozco said, "and there we are running a risk because we are risking a sale. And that hurts business."

Fitting this operation into production lines with a global reach was a challenge. "At this site, we have two assembly plants," Orozco continued.

Plant I produces sedans. Plant 2 produces trucks. But then we have a third shipping point for what we call different market characteristics. [That third shipping point] is where we have vehicles going to the United States, Brazil, and Europe. That line doesn't have the REPUVE because they are exports. . . . Periodically, however, we receive domestic vehicles here. So this means having the [REPUVE] infrastructure in three spots. . . . Like I said, this doesn't add any value to the vehicle from the business point of view.... Whatever addition that is going to be added to a vehicle has to be controlled under various measures of quality. All of this has an expense, a logistics. . . . We return to the same point. This [RFID tag] didn't have a benefit for us as a company.

The direct costs of applying the tags did not exhaust auto producers' friction with the program. Aesthetics also mattered. This point was first shared with me by Tomás Ayala and Vicente Bautista at the REPUVE's Procedures and Citizenry Directorate. "The sticker," Ayala plainly said, "is not the most decorative element." As a result, he continued, "the car producers put up a lot of obstacles for sticking on the tag." The VMC representatives I met with confirmed these points of discord. "That a vehicle that is sportier, and more expensive then, has to have this sticker," Fernando Orozco opined, "for us that is horrible."

Beyond aesthetics, the industry was also concerned about safety and the impact that the tags might have on drivers' visibility. While VMC 
and Sucaro were placing the stickers on the upper-middle part of windshields, above the rearview mirror, the ideal placement recommended by the REPUVE, they harbored concerns. Orozco at VMC explained, "I'm not going to lie that the best option economically and technically would be to place the chip on the lower right-hand side of the windshield, because you as a driver in Mexico, all of the driving is on the left. It wouldn't obstruct a traffic light or a sign on that side. Some manufacturers put it on the upper-left side. But putting it on the lower-right side would have practically no consequence. That is, it's there visually, but there's no risk to visibility."

\subsubsection{Corruption Concerns}

Transnational corporations that produce and import vehicles in Mexico were not the only companies concerned about the Public Registry of Vehicles. Following my field visit to Zacatecas, a local newspaper ran a blurb about my research. Once the piece appeared online, I was contacted by Jonathan Vargas, a representative from the SecureRead company, which had competed for the contract to produce REPUVE tags. That concession was ultimately awarded to the Neology corporation, a company owned by Alejandro Burillo Azcarraga, a member of the influential Azcarraga family, which founded the Televisa television corporation. Burillo himself has a wide variety of business interests, ranging from soccer clubs to mobile telephone providers. On the phone, Vargas told me that he felt the need to share his version of the story of how Neology won the concession for REPUVE tags.

The concession, as national newspapers reported, was based on a trial of different RFID technology providers that took place at the Autódromo Hermanos Rodríguez, a well-known racing circuit in Mexico City that hosts Formula One races. The competition was presided over by technical advisers from three of Mexico's leading universities: UNAM, the National Polytechnic Institute, and the Institute of Technology and Higher Education of Monterrey.

Describing his company's experiences with the competition, Vargas started by focusing on the differences between active tags, which SecureRead specialized in, and passive tags, which Neology produces:

The operational minimums that they showed in the presentation can correspond only to an active tag. They had to be able to read multiple vehicles in traffic, be able to read from a mobile terminal that was in a patrol car, and be able to read from the side of the road at a certain speed. And I think they 
wanted 99 percent accuracy. All those are things the active tags can do, not something the passive tags can do.... We thought this presentation matched something that we can deal with. So, we wanted to do the trial.

\section{"At the Autódromo Hermanos Rodríguez," he remembered,}

we were the last to go. We were one of two active-tag companies. Everybody else was passive. ... So we were the last ones. We went immediately after a company called Apex. They were having some problems with the readers. They were having problems with passing the bridge. And other things like dirt and rain. Anyway, at the end of the day it started raining and pouring. And the guys were like, "You are not going to be able to work." And I said, "No, absolutely we can work. We're active. It's different." The professors that were evaluating the technology, they knew nothing about active. All their protocols were all about passive tests, you know one vehicle, one per lane, not in traffic. . . . They knew active existed, but they hadn't designed a protocol for it. ... Anyway, we run our test and then we had a representative from one of the other large companies come up to us [after] and say, "Hey, why are you here?" We said, "Well, you know we are running this test." And he said, "No, sorry, it's already been decided. Neology is going to win. That's what I've been told." At first, I was a little shocked. So we asked for a meeting with this Campa Cifrián, with the head [of the Executive Secretariat of the National System for Public Security (SESNSP)], the guy that was running REPUVE, and effectively that's what we were told ... "It's has already been decided, it's going to be passive. I can't tell you who is going to win, but it is going to be passive, you are too expensive."

Vargas's account carries a tinge of sour grapes. But it should be noted that corruption in public procurements in Mexico is common and problematic. Indeed, the Organisation for Economic Co-operation and Development has remarked that the lack of a competitive bidding system encourages collusion between bidders and reduces the viability of international suppliers. ${ }^{38}$ What is more, SecureRead was not the only company flummoxed by the conduct of the trial. After its completion, the REPUVE competition was featured in media reports that cited a "lack of transparency in the results of the evaluation decision." 39 Firms that took part, including Integra, Mobil-link, and e-Plate, complained that they did not have sufficient details on the types of tests to be done prior to the competition. ${ }^{4 \circ}$ Roberto Campa Cifrián, head of the SESNSP mentioned by Vargas, was also accused of being tied to one of the companies with a stake in the bid, the Cosmocolor Company, which produces holograms for stickers like those used in the REPUVE and is owned by Jorge Kahwagi, whose father is president of Mexico's Confederation of the National Chambers of Commerce. ${ }^{4 \mathrm{I}}$ 
In addition to the intrigue about Campa Cifrián's links to companies bidding on the REPUVE contract, Vargas's story references a central technical issue at stake in the competition-passive versus active RFID technology. Experts cited in media reports argued that the passive tags chosen by the SESNSP "have disadvantages such as their read coverage and the cost of some of the reading equipment (like arches at highway exits), which go from 2,000 to 25,000 dollars." Active tags, meanwhile, "cost from I 2 to 25 dollars [and] have readers that cost from 300 to 500 dollars, some as small as cellular phones." Put another way, "With the active technology, the reader identifies all the tags located in a determined area, which facilitates their search in wide spaces, while the reading of the passive tag is individual and at specific points." ${ }^{42}$ Given the seeming advantage of active tags over passive tags, the media reports added to the controversy surrounding the bidding process."

By the time I was conducting my research, the national directors of the REPUVE within the SESNSP considered the controversy over active versus passive tags "a debate already decided" and one that "owed to different interests" rather than technological considerations. Tomás Ayala and Vicente Bautista shared Campa Cifrián's view that while "the active tag had advantages from the point of view of coverage, ... the two points that were of greatest importance for us were the transferability of the tag ... and the fact that the battery at that time could last, at best, four or five years." Ayala stressed, "The moment that these batteries stop functioning, the tags would obviously stop functioning, and you would have to devise a replacement of the batteries and all that that would mean for twenty-five million vehicles." But if the program administrators considered the matter closed, the debate, even if

a. In the midst of the controversy, Campa Cifrián was called to testify before the Internal Revenue and Public Credit Commission of the House of Deputies, Mexico's lower legislative chamber, to explain his decision on the bid. He had earlier explained that the decision was based on recommendations of the evaluation team from the three universities, who took into consideration the life span of active versus passive chips, the lower costs per unit for passive chips, and the fact that passive technology was open source and not subject to proprietary restrictions. Unconvinced by the his explanation, the committee demanded Campa Cifrián's resignation and cancellation of the concession, because passive technology was insufficient to stop organized crime and vehicle theft (de la Luz González, "Eligen chip inútil contra robacoches"). The passive technology stayed. But a week later, Campa Cifrián did resign (de la Luz González, "Roberto Campa renuncia al SNSP"), although questions persisted as to whether his boss, Gerardo García Luna, the powerful head of the Public Security Secretariat (SSP), had penned his letter of resignation (Rodríguez, "Campa Cifrián-García Luna”). 
fed by disgruntled businesses and headline-seeking reporters, had cast the REPUVE's bidding process in doubt and, in the process, diminished the program's legitimacy in the public eye.

\subsubsection{Program Confusion}

In addition to car producers and tag manufacturers, car dealers make up another another sujeto obligado (obligated subject) from the business sector that have a role in implementing the REPUVE. Dealers are a key actor for the registry because, in selling vehicles to the public with chips already adhered to them, they serve as a point of contact between the registry and the public. In summer 20I2, I visited dealerships around Mexico City to get a sense of their role as informal ambassadors for the Public Registry of Vehicles. When I asked salespeople and other employees, "What are the tags on the vehicles for?" answers varied. Most described them as "customs stickers" applied when "when cars are imported, so this [sticker] is for when vehicles pass through customs."

These responses are partly true. Mexican customs offices are required to apply REPUVE stickers to vehicles that are imported directly from the United States. And the customs database feeds into the REPUVE database. But the responses also fundamentally confuse the purpose and operation of the REPUVE, which is to provide for "legal certainty" of vehicles by applying a tag to every vehicle in the country without distinction of country of origin. Of the ten dealerships I visited, only one offered a description of the tags that matched the REPUVE. "It is a government rule that [the sticker] has to be there," the salesperson explained, "because if it isn't, the car can be considered stolen, that it didn't enter the country legally."

When I mentioned these interactions in an interview with officials at the Relations with Obligated Subjects Directorate, Fernando Nava acknowledged that "there is a large lack of knowledge present, above all concerning the composition of the REPUVE for the sujetos obligados. Windshield installers or body shops are sujetos obligados by law who protect and maintain the tags. However, many windshield installers, I don't know if they are aware of the program or if they aren't dealing with the REPUVE. They do what they want with the chips." Given this lack of information, Nava continued, more had to be done to "inform dealers why the chips are there, so that they don't remove the stickers without knowing why they're there, and to inform buyers in case they ask, so that they know how to answer them. [There could be] cases 
where a new vehicle is damaged and the windshield had to be changed, and the vehicle doesn't have a tag then. Then, if buyers were to come in and see the vehicle and don't see the tag, they would say, 'I want my tag.' Maybe they don't know exactly what it is, but they want it."

But if the car dealers did not know why the stickers appeared on vehicles, they were unequivocal on the question of whether they could be removed. Every dealer I spoke with said they could not be removed. But rather than referring to the REPUVE law by name, respondents noted that, "on the streets, traffic police check stickers often, to see whether the car has it or not. And if they're going to stop you and you don't have the sticker ..." Or, as another salesperson told me, if your vehicle does not have the sticker, "then later you can have problems if one day you are stopped or you have your car stolen or you have an accident and they are going to check the numbers in the registry, and if you don't have it, there's going to be trouble."

This is an interesting point to reflect upon. The dealers do not understand why the REPUVE tags are on their vehicles, but they are unwavering in communicating that they cannot be removed. In this sense, to put it in sociolegal terms, the dealers stand "before the law" and follow its dictates without knowing what the law actually is. ${ }^{43}$ This dissonance can be explained, perhaps, by the history of policing automobility in Mexico more generally, which was covered in the last chapter. The presence of regulatory stickers on vehicles is nothing new in Mexico. And in Mexico City, pollution controls are enforced in part through stickers, which the police monitor. Thus, if the REPUVE sticker is itself is an unknown entity, it represents something common to those working around automobiles and thus fits into a broader pattern of experiences and practices surrounding that thing.

The experiences of car dealers with the REPUVE also contrast in interesting ways with those of car producers. If car dealers were ignorant of the REPUVE law, car producers were only too aware of it, and they actively disliked it. But unlike mobile phone users refusing to register their phones, manufacturers did not stand "against law." Why the difference? Quite simply, the risk of sanctions for noncompliance with the federal law was too great. Julieta Salazar, from the REPUVE's Relations with Obligated Subjects Directorate, told me that "the private sector has always been very strict, above all the big companies, with relation to legal compliance with the federal and state governments. It's not easy for their legal teams to know about a law or regulation and not comply with it." 
This point was repeated by the company representatives I spoke with. But additional factors besides the power of the law came into play. "Why does VMC comply with the REPUVE law?" Fernando Orozco reflected. "VMC basically has soo percent compliance with the law, not only the REPUVE law, but with all the laws, economic, import, customs, et cetera. We are the most precise and maybe the most compliant in the entire industry. ... [The REPUVE] is a severe operational expense. However, the law was passed. The regulation was made. We had to comply." Here Orozco finishes by noting the lack of options available to VMC to ignore the REPUVE law. But additionally, he speaks with a certain satisfaction about the compliance rate of VMC with the law in general. Legal compliance, to him, is an extension of his company's exacting approach to industrial production that allows it to send a vehicle off the production line every eighteen seconds. Thus, a certain company culture was present at VMC that leaned toward compliance.

In the case of Sucaro, national culture was cited as central to compliance. Sucaro is based in Asia. And Agustín Sandoval and Felipe Ibarra felt this helped explain their company's stance with the REPUVE. "We, as a subsidiary company, report absolutely everything to Asia," Sandoval told me. "A program such as this has so many implications, legal as well as social, from the point of view of drivers. We translate all of this, including the rules and regulations, so that it is absolutely clear. On other hand, the Asian philosophy is very precise, very dignified in the sense that if the law asks me to do this, I have to comply." Ibarra added,

There are companies that are more rebellious, that in a given moment would sue and not comply. But the Asian companies aren't like that. Without mentioning brands within the automotive industry, there have been two extremes, from two powerful companies. One takes any minor pretext to say, "I'm done with the chip. Let the government do it if it wants. I quit! No more!" The other has said, "I already invested millions into the manufacturing process, from the wheels on down, everything is almost robotized. The process of putting on chips? I can do it, I already spoke with corporate about it.

These responses seem to suggest that VMC and Sucaro had assumed a stance "before the law," choosing to comply with its dictates, whether because of the exacting nature of the company or its national corporate culture. But this does not give the entire picture. In an email, Julieta Salazar explained that the auto producers "accept it [REPUVE], but 
are insistent" that the government take over the job of applying tags to vehicles. "It's always a point of discussion," Salazar continued. "In fact, right now, there is a lawsuit through the Mexican Association for the Automotive Industry (AMIA) to reform the law where they propose that the states do it... They insisted that the federal Secretariat of Public Security (SSP) would be the better option for conducting this activity. Even when there is an agreement with the Association, they haven't stopped in their initiative to reform the Public Registry of Vehicles Law so that that obligation would be done away with." In this sense, the automobile industry can be seen to assume a position of "resistance by means of law." ${ }^{44}$ Companies like VMC and Sucaro have complied with the REPUVE, analyzing and altering their production operations in order to apply tags to vehicles without disrupting car sales. But at the same time, through their national association, they are using the legal avenues available to them to eliminate the legal requirements that they view as especially burdensome.

\subsection{THE OBSTRUCTIONS OF STATE: RESOURCES, LEADERSHIP, POLITICS, AND ORGANIZATION}

If the stances of laypeople and business actors toward the RENAUT, CEDI, and REPUVE can be mapped onto existing frameworks for comprehending resistance, this correspondence begins to unravel when considering another key point of opposition to the programs: the state itself. As noted at the beginning of the chapter, the primary source of opposition to the Citizen Identity Card came from the Federal Electoral Institute, an independent governmental body charged with regulating elections. In the case of the National Registry of Mobile Telephone Users, strong public opposition enabled politicians to question the program, and the Communications Commission of the House of Deputies called the RENAUT's leadership to testify about the program's difficulties. ${ }^{45}$ With the Public Registry of Vehicles, meanwhile, states have been reluctant to begin applying tags to vehicles.

This is a critical point. One might assume that the state would support government initiatives, especially in the realm of security. But as Daniela Flores with the REPUVE's State and Federal Operations division described to me, there are multiple reasons why working with the state proves difficult: "One is resources, two is the will to do things, three is the political aspect." To this list could be added the organization of state power. 


\subsection{Budgetary Constraints}

A federated state's implementation of a program such as the REPUVE requires a sizeable investment in resources. These include, at a bare minimum, computers to process information, printers to print out tags, handheld RFID readers to activate and verify chips once they are adhered, and facilities and salaries for workers in the program. Some of these resources can be paid for by the federal government's Support Funds for Public Security (FASP), monies provided to the states for public security expenses. But discrepancies between allocations and costs can be great. As one member of a Mexico City delegation explained at a national meeting on the REPUVE that I attended, "We have a registered vehicular roll of four million vehicles, we received three million tags, and from the federal project budget we have 7.5 million pesos assigned this year. But we have estimated that the implementation will cost 240 million pesos."

But tags are only a portion of the program costs. To fully register the presence of a vehicle at a transit point, the REPUVE also requires license plate recognition (LPR) technology. LPR technology, however, "has the disadvantage of being very expensive equipment," a point emphasized to me by Ignacio Meza, the official with REPUVE Zacatecas. Workers there also believed that the program needed better facilities than the trailers they were operating out of. Matías Luna, a data specialist, thought that "for this program to function better, adequate space is needed":

That includes a tarp. That includes a space for the clients, for when, say, four, five, six vehicles arrive. Normally, at least two people come in a car. If five vehicles come, you have ten people-where do you put them? Sometimes the sun is very strong, and twenty minutes standing out here in the sun is a lot. It burns. So I think that there should be an adequate space for the clients to wait for the fifteen to twenty minutes that the process takes. For the technicians too. They do the physical work. It's hard. So, the same thing. Have a tarp or a tent to protect them from the sun, so that they can do their work despite inclemency of the weather.

Another member of the REPUVE Zacatecas team felt that more resources were needed to attract people to the program: "The program, in terms of its goal of installing chips, has certain deficiencies. Advertising, for example. They haven't been able to advertise it in a way that the people in the state understand its purpose or importance for why vehicles will have a chip. This is the reason why there have been few people coming for the installation of chips." 
Without the dedicated funds for the program, many states announced suspension of its implementation. For example, Fernando Manrique Rivas, director of Vehicular Control in Morelos, explained that the REPUVE “isn't only putting on a sticker, it's putting in place all of the infrastructure that is going to read and keep the institutions of public security informed. So it is a costly program that today doesn't have sufficient resources. For that reason, the program is suspended." ${ }^{46}$ One detects an element of political opportunism in such actions. States shutting down or threatening to shutter federal programs for lack of resources may simply be maneuvering to secure more resources from Mexico City, a dynamic reflective of the strong regionalism that has long defined the country. ${ }^{47}$ Indeed, this angle was noted by the State and Federal Operations Implementation members I spoke with. Lucas Espinoza explained, "There is also the political part. The federal government can be pressured to give money that is required. And if San Luis [Potosí] gets more, then Zacatecas is complaining to get more too. Because at the end of the day, it's not their money, it's the citizens' money."

There is a prudential element at work here as well, which is potentially troubling for a program like the REPUVE. Because the FASP used by the states to implement the program are not earmarked and are intended to cover all state public security projects, the more invested in the REPUVE, the less goes into other security priorities. As Ignacio Meza from REPUVE Zacatecas noted,

There are states that have, apart from the federal resources, invested money from their own governments, against their own accounts. But they are few. Two or three states have done that, like Veracruz and San Luis Potosí. They're achieving the same numbers [of registrations] as we are. But other states that are taking money from the public security funds, they are putting money into REPUVE and leaving little for public security. In the case of Zacatecas, public security is being given priority, and this leaves small change or few funds for the REPUVE. From the same funds, you have police training, equipment, and other things.

Not only that, Meza continued, but "if I invest in an advertising campaign to tell people what the program is about, I don't have the technical capacity to respond." That is, an advertising campaign might help attract drivers, but the resources invested there would come at the expense of program capacity. He added, "The moment that I do the advertising campaign, I am going to have a rush for fifteen or twenty days in which the whole wide world, even if they don't have cars, 
are going to go to the webpage and want a consultation. This would overwhelm the system, it would be a disaster. We are at a crossroads of technology, necessities, and the rest, which doesn't permit us to advance at the pace that we would have wanted." Thus, a cycle of lethargy befell the REPUVE. States were unwilling to invest in a program they did not see as a priority and that lacked popular demand. But if that demand were there, they would not be able to handle it. So the most rational course of action was to not invest in the program at all.

This situation bred frustration among the data specialists and technicians working at REPUVE Zacatecas. Part of the frustration was understandably selfish. Matías Luna confided to me, "A pay increase would be good. I don't know how much it should be, but I would like it if it were more. Really, whatever you earn, people make what they make, but it's never enough." But the frustration of workers involved more than personal interests. "One of the things that I don't think has functioned well is the interest of the government to start things off well," Diego Avila, a technician in Zacatecas, told me. "San Luis has taken off. Veracruz has taken off. They have taken off because of the interest of the government. They have put everything into it. Here, it's like they're a bit afraid, or they've forgotten about us."

The frustration extended beyond the frontline workers in the program. Ignacio Meza faulted the fact that the amount of the FASP received by states was based on population rather than expediency. "Take a state like Chihuahua," he told me, "which doesn't have the population that the Federal District [Mexico City] has, but its crime level is extremely high. It doesn't receive the funds that it should. The Federal District receives more, although the crime level isn't so great. So there are questions about the formula [for allocating resources]. At the end of the day, the resources are there."

Further, the frustration over resources extended to the national leadership of the REPUVE as well. "Another obstacle that we have encountered," explained Samuel Gallo with the State and Federal Operations directorate, is that "we don't even have the support here to have the budget that would allow us to push certain things forward." Elaborating, he said, "There are different factors that prevent the process from being more agile. A first point is resources. The program doesn't have an adequate communications system. There are not sufficient blueprints. There is not sufficient equipment. It's a significant obstacle to our being able to share information.” 


\subsubsection{Political Leadership}

This frustration over resources speaks, in turn, to the second aspect Daniela Flores saw as lacking in the federal government's implementation of the REPUVE: the will or leadership to get things done. "Look," Samuel Gallo lamented, "this project has a very large potential, but sadly it has not been seen as such in the upper spheres, not at the presidential level, nor the interior secretary level, nor the Public Security Secretariat level. They haven't given the program the impulse that it should have." He continued, "It's the political question, it's the question sometimes of leadership, in a way it's a lack of leadership to shake things up." These comments echo the exchange between Lucas Espinoza and Daniela Flores that begin this chapter. Even within their own building, the offices of the SESNSP, the REPUVE team felt invisible. Not only their work, but the importance of their program was being ignored.

The lack of will to get things done extended down from the federal government to the states. As Gallo explained, state authorities, such as the attorneys general in charge of tracking vehicles, were often remiss in updating their databases: "There are national accords that the prosecutors, and even governors in some cases, signed and promised to send information in no more than seventy-two hours in the case of stolen vehicles. . . However, for questions of, I would tell you, resources, political situations, lack of personnel, et cetera, not everyone manages to comply with it. We have a substantial lapse of time in knowing if a vehicle is stolen or not." He elaborated,

In theory, everyone should be analyzing their information on a daily basis. . . But it doesn't happen. There are states that update on a daily basis. There are states that update every twenty-four, forty-eight hours. There are states that wait fifteen days up to a month. ... Let me give you an example, from the State of Mexico, one of the largest states in the country. It's the state that has the largest number of stolen vehicles. In other measures, it also has a high level of crime. The State of Mexico receives the greatest number of federal resources, in this case, with the [Support] Funds for Public Security. They receive more money than the Federal District. And it is one of the states that generates some of the greatest amount of state funds by itself. And they have these types of delays. But I should also mention Tlaxcala. It has very little money, being a very small state. The population is small. So, the formula that exists for assigning resources leaves it receiving a tenth of what the state of Mexico receives. However, when the will to work is there, results can be achieved.

The lack of desire to achieve results was felt at the local level too. Matías Luna at REPUVE Zacatecas proffered that one modification he 
would make "would be to incentivize the personnel. I'm not talking about money. I'm saying there should more supervision of how you're doing your job.... And there should be supervision. It's a form of incentivizing the personnel to work in this program. . . . You've been here a week and you haven't seen anyone come to say, 'Hey, how are you doing?' I'm not saying they should be all over us here. But once or twice a week, have someone come to check. This incentivizes the personnel."

\subsubsection{Political Interests}

At times, the complications with implementing the REPUVE at the state level reflected not a lack of will on the part of state authorities but competing political interests, Daniela Flores's third point. As Samuel Gallo bluntly told me, "Hay colores," or "there are colors," by which he meant political affiliations at work." "It's like the case of Sinaloa," he explained.

Sinaloa is drowning in crime and all that. But it's priista [ruled by the PRI, the Institutional Revolutionary Party] and it doesn't share the ideas of panismo [of the PAN, the National Action Party ]. The guy who became governor of the state was one of the principal detractors of the idea that the REPUVE had to have a chip.... Now the program is stalled because the governor was one of those who at the time didn't accept the passive chip. He wanted it to be active. He was going to sign a contract with a LoJack type of service, that type of satellite service, which has a higher operating cost, much much higher cost, than what we are implementing.

"Look," Gallo continued, "there are many questions that get in the way. I can tell you that Sinaloa is serviced now by the technology supplier who the Executive Secretary [SESNSP] is suing for having registered the website REPUVE.com. So there is a lawsuit launched by the Executive Secretary against this supplier, which is the supplier for Sinaloa. So there are interests. There is a conflict of interests." According to the State and Federal Operations directorate, the active-tag provider to whom they were referring-a Mexico City company named

b. In Mexico, as in many parts of the world where literacy rates have historically been low, political parties are often identified by colors or objects as much as by name. The Institutional Revolutionary Party, as the hegemonic political party following the Revolution, was able to wrap itself in the colors of the national flag: red, green, and white. The right-leaning National Action Party, which held the presidency from 2000 to $20 \mathrm{I} 2$, adopts blue as its primary color. The third major, although comparatively smaller, party, the Democratic Revolution Party, colors itself yellow. 
Socom-had publicly registered the name REPUVE in 2007 , which was after the signing of the REPUVE law but before the decision was made on chip design and contractor. ${ }^{48}$ In essence, the disputes over passive and active chips and the awarding of the REPUVE contract were continuing to complicate the implementation of the program. This situation underscores the variety of interests at play when "colors" are involved.

REPUVE administrators saw such conflicts of interest as endemic to Mexico. When I asked about the adequacy of resources for states, Gallo responded, "There's money. But it's poorly distributed. And the problem of distribution comes down to political networks. So, this is the problem. In those networks, someone is the mayor. Below him are his buddy, his son, his godson, and all of the family is occupying the political system." Daniela Flores added, "They are the ones who take the salaries. And that's where all of the money stays. They get $\$ 60,000$, but it's divided between the same family." "And that's how you create these empires," Gallo continued, "this is how the monopolies are created. And when they leave power, new businesses and consortiums emerge. So this is the problem in the country. Because there exists this circle of impunity. Every three or six years," the length of time that someone serves in office in Mexico, "there are new rich people. This is impunity. There are no accusations. There is not legitimacy. Because if I accuse you today, I get kidnapped tomorrow. And they're going to split my head open. So why would I make a complaint?" Gallo and Flores reference here the personalistic political networks that have defined Mexican political life since at least the establishment of caciquismo (rule by local political chiefs) during the conquest. ${ }^{49}$ While its forms have surely changed, ${ }^{50}$ clientelism remains endemic in Mexico, ${ }^{5 \mathrm{I}}$ and democratization has thus far proved incapable of rooting out such "old corruption." formations complicate the federal government's efforts to change the governance of automobility in the present day.

\subsubsection{The Organization of State Power}

Even when the resources and will to advance a program are present and deleterious political interests are absent, other political forces can intervene. For instance, the obstinacy of state governments to carry out the plans of federal administrators is provided for under the law. Within Mexico's federalist political system, which reflects the country's long history of dividing political power among regional strongmen, ${ }^{53}$ federal law does not apply to state governments the way that it does to private 
corporations or individuals. As Vicente Bautista with the Procedures and Citizenry Directorate explained, "The problem that we are having these days is that the private industry, the producers, Ioo percent are participating. But the law requires them to ... the states are autonomous. Free and sovereign. We cannot sanction them. We have to convince them. That's the challenge for us." When I asked whether the government also had the power to withhold federal funding, such as the FASP, to encourage states' participation, Bautista was quick to reply, "No, no. We have security funds from the federal government that are allotted to them [the states]. But they decide how to distribute them according to their own priorities."

"This is one of the gaps," Samuel Gallo conceded. "It's something the law didn't take into consideration. The law stipulates that the factories, the importers, the law can grab them by the throat. It has them in its grasp. It can fine them if they don't comply. That part is taken care of. But since the constitution establishes that the states are free and sovereign, it isn't easy to establish these types of sanctions. It would never get passed by the Congress."

The Citizen Identity Card faced a similar obstacle in the organization of political power in Mexico. The CEDI ran up against existing state bureaucracy-that of the IFE and the voter card-established in an earlier era to fulfill similar functions. The duplication in function, and the threat posed by the new program, fostered political entrenchment aimed at preserving the IFE's authority. As IFE president Leonardo Valdez Zurita explained in opposing the CEDI, "the Card will negatively affect two of the pillars of our political system: the voter roll and the voter card" and even if the CEDI is "undoubtedly legal, from my point of view it's electorally unfortunate." 54

In addition to the federated structure of power in Mexico, the Constitution only allows elected officials to serve single terms in office, a provision motivated by Porfirio Díaz's long tenure in power (I876-I9II). For REPUVE program administrators, this constitutional guarantee against dictatorial rule created political turnover at the state level that affected the program's success. In Zacatecas, for example, which had been one of the leading states in applying RFID tags in 2010, a change from a Democratic Revolution Party (PRD) governor to a PRI governor was felt to disrupt the state's progress with the program. As Ignacio Meza from REPUVE Zacatecas delicately put it to me,

I don't know if you have read about it or seen it, there was a PRD governor here in Zacatecas that changed to the PRI, the Institutional Revolutionary 
Party. There's a certain rivalry there. We don't see each other as citizens, but as enemies. And this has put the brakes on the process a bit. Other factors, such as the economic situation, have had an impact as well. This is a program that has to carry two enormous weights on its back. One, the federal government is panista [controlled by the PAN]. The other, it [the program] was begun by a perredista [PRD] government. So this hasn't permitted the push that these programs need, in contrast to San Luis [Potosí] or Veracruz. In Veracruz, the current government is the one that launched the program. There hasn't been a change of government. In San Luis, the same.

For the program's national directors, such cases spoke to larger challenges in the country. "The sad history," explained Samuel Gallo, invoking the legacy of presidencialismo, or the PRI's concentration of political power in the executive branch, ${ }^{55}$ "is that whenever someone gets to that chair [presidency, governorship], everything changes. The problem is the chair. There is the sensation of power. Then all the good promises, all of the hopes that were built up, they begin to dissolve. They are not able to put into action even 50 percent of the campaign promises that they have. And now, in the next elections, there will be another change."

Instead of continuing a previous administration's policies, new administrations, Lucas Espinoza and Daniela Flores felt, resorted to populist tendencies and pursued more visible public works to win the support of voters. "Something unfortunate about the government here is that they want to show results quickly," Flores told me. "But you have to start from zero and it's going to take years, ten, fifteen years maybe [to get something done]. And they're not interested in that. Most of the alternatives that an administration has available to it are to take the populist route. It's better to construct a bridge than a highway, which looks sensational. So I'll get you a park. I'll get you a bridge. And that's that." "But then there are people who'll tell you," Espinoza halfjokingly interjected, "we don't have a river [for the bridge to transverse]. "Ah, well," Flores took back the thread of the conversation, "let's make a river too then! These are the types of illogical situations that there are." Placing themselves within the country's historical-political context, the REPUVE's directors saw their program as a victim of populist tendencies produced by political turnover.

As Flores's comments suggest, this political dynamic was present not only at the state or local level but at the national level as well. At the REPUVE national offices in 20I I, a year before the end of Felipe Calderón's six-year term and a presidential election that most thought 
would be won by the PRI, ${ }^{c}$ a mix of frustration and concern for what a change in "colors" at the top of the political ladder might mean for the program was palpable. "Unfortunately for us," Gallo shared, "we are a year and a half away from a change in federal administration. So important decisions are not going to be made. No one is going to dare tackle a problem or confront an institution because it's not going to matter. So, now, all the activity is going to start to go down and that is going to continue until the middle of 2013 and then begin to rise again. This is the change of administration. With a change of administration, new brains arrive. New ideas. And the continuity is broken."

The preceding points illustrate how forces beyond the actions of human actors, be they individual laypeople, corporations, or political parties, have affected the destiny of security surveillance programs in Mexico. The absence of adequate funds with which to launch programs, budgeting procedures for the expenditure of funds that do exist, nepotistic political practices that date back to colonial and pre-Columbian times, the arrangement of federal and state political authority and limitations on tenures in political office enshrined in Mexico's Constitution, and the presence of extant state authorities and programs created during earlier periods all illustrate the manner in which the structure of the state-the existing arrangement of rules, cultural practices, and governing bodies for conducting public affairs—can impede the establishment of new modes of governance.

\subsection{TECHNICAL IMPEDIMENTS: DESIGN, SCOPE, AND GLITCHES}

The challenges that the National Registry of Mobile Telephone Users, Citizen Identity Card, and Public Registry of Vehicles have encountered demonstrate that obstacles in political and state affairs emerge from multiple sources. This point is even clearer in light of the multiple technical difficulties the programs have faced. Three types of issues have loomed especially large: program design, project scale, and technical malfunctions.

c. And indeed, in July 20I2, Enrique Peña Nieto, former governor of the state of Mexico and member of the PRI, was elected president by an electorate tired by the previous administration's focus on security issues at the cost of broader social and economic concerns. 


\subsection{Program Design}

Poor program design hampered the RENAUT in particular. Despite popular resistance to the program, some eighty-two million mobile numbers were ultimately registered with the government, ${ }^{56}$ representing 90 percent of all mobile lines in the country. Amid reports of dubious registrations, however, the government turned to verifying or inspecting the associations between phones lines and individuals. This would, in theory, be accomplished by comparing the names and dates of birth or CURPs associated with a particular number to the National Population Registry (RENAPO) maintained by the Interior Secretariat. How that task was to be accomplished however, or who would be responsible for it, was not clear.

Government officials, such as Mony de Swaan, president of the Federal Commission of Telecommunications (COFETEL), claimed that mobile telephone service providers were supposed to complete the work. "The registry itself has been successful. There are substantial numbers [of registrations]," de Swaan explained. "But where we have not been successful is in linking these registrations with the biometric characteristics of the user. We are in a stage where the registrations have to be linked with fingerprints. We need an analysis to know if this is working or not, because COFETEL cannot do the analysis. It's not our job. We don't have the capacity to do it." ${ }^{27}$

Industry representatives, on the other hand, countered that they had no knowledge of such requirements. Jorge Arreola, compliance director of Telefónica México, told the press that "the problem we have is with respect to the mechanism by which a CURP can be used to register a phone of some other person," the problem of the ten thousand Calderóns noted at the beginning of the chapter. The verification of identity was supposed to be undertaken by the Interior Secretariat, Arreola claimed, but “this project didn't move forward and we don't know if there exists a procedure that would allow us to move forward." ${ }^{8}$ The uncertainty and lack of a clear plan to carry out the second stage of the RENAUT threatened the feasibility of the program moving forward.

Program design also affected the REPUVE. In 200I, before the REPUVE was born, the SESNSP, the governmental body that oversees the registry, moved from the Interior Secretariat (SEGOB) to the Secretariat of Public Security (SSP), a new agency created by then president Vicente Fox to fight crime. At the time, the SESNSP had responsibility for various technical operations, with direct control over the creation 
of databases related to security. During the Calderón administration, the SSP became the central pivot for security operations, including control over Plataforma México, the information system hosting and integrating various government databases; and the SESNSP returned to the SEGOB in 2009 , on the logic that vital security functions should be housed within the Interior Secretariat. In the process, members of the REPUVE project felt like they lost contact with the technical support in the SSP needed to complete their work.

"In 20I0, we as REPUVE ceased to belong to the Secretariat of Public Security and we went to the Interior Secretariat," Lucas Espinoza told me. "Over there stayed the technical part. So we lost another part of our history. And now, as the Executive Secretariat [of the National System for Public Security], we don't have a technical area that serves us, we don't have a technical area for development that can attend to the specific needs of this institution. All the time we have to ask favors from Plataforma México." Daniela Flores added, "And we have to stop everything for them to notice us. We moved from being a complete administrative unit to being third-party clients."

The loss of access to technical solutions, as Flores hinted at, resulted in delays. "We have had a series of complications with the technical aspects," she explained, "They [Plataforma México] don't have the capacity. . . . So I enter a queue, and they are assisting everyone else. I have a spot in the line and however hard I try, they can't get me the requirements like I need them." The delays, in turn, complicated the State and Federal Operations team's interactions with the states. Flores continued, "So we can't give the states adequate tools, so that everything keeps working. And then they lose interest." "We have the [software] applications now," Samuel Gallo interjected, "but they were two years late. If we had had these applications last year, we would have implemented more than 50 percent of this project. If Plataforma México had given me the applications when I needed [them] last year, we would have 50 percent of the states working [with us] and I wouldn't be worried about anything more than six or seven other states. In 20I 2, we'll certainly lock them up. But these are the gaps.”

These concerns over the organization of work and program design appeared at the local level too. In Zacatecas, technicians inspecting vehicles complained that they did not have access to the stolen vehicles database to facilitate their work. Instead, they had to call over to the prosecutor's office to access the information. Matías Luna grumbled 
that the software "doesn't have some of the features that would help the work go easier. For example, we have to do a report, a report of not being stolen when we are verifying the VIN [vehicle identification number]. We have to pull a report, but we have to depend on another office in order to be able to pull it. Why can't we use the same software so that, when we type in the VIN, it can tell me that or give me the report automatically?"

These comments from those on the frontline of REPUVE's rollout in Zacatecas and those working in the SESNSP's national offices suggest limitations in prohesion as a mode of governance. As governmental agencies are increasingly integrated through centralized electronic databases, access to those centralized information networks becomes indispensable for those agencies to do their work, while restricting access is fundamental to maintaining security. A rivalry develops, between the desire for the state's bureaucratic tasks to be completed in a timely manner and the demand for the information the state is administering to be safeguarded.

\subsubsection{Project Scale}

Even when the programs were operating without major complications, they were challenged by the immense scope of the work to be completed. The State of Tlaxcala, for instance, held out earlier by Samuel Gallo as a model for the states' implementation of the REPUVE, was able to apply chips to some twenty thousand vehicles within six months of beginning operations at two REPUVE sites, an impressive rate of forty vehicles per day. However, that success represented only io percent of the state's vehicular roll, leaving the program years short of covering the entire population. ${ }^{59}$ To provide another example, the State and Federal Operations directorate described how it had succeeded in creating a centralized database from the vehicular data from all thirtytwo federated states. But the enormity of the task cost the office years to complete. Gallo explained,

We asked the thirty-two states, "Give us your databases," and we reviewed them, one by one, taking out trash, taking out duplications, all of this, in order to have a trustworthy database. We were roo percent dedicated to reviewing each of the registries so that they were complete, so that they weren't duplicated, so that they didn't contain trash. [But] one problem was the great diversity in record keeping. We would find cars that were registered in three, four, five different states. They hadn't been removed [from other 
states' vehicle rolls]. Sometimes, they had typed in Volkswagen and put $b$ in place of $v$, and they would write Ford without the $d$. So we had a lot of data-entry errors. Lots of trash. Omissions. This process took us three years. We took three years to clean the database.

This editing is precisely the type of cohesive work expected of the REPUVE in integrating the data systems of diverse entities. But the sheer scale of the task, combined with the limitations of Plataforma México and a lack of resources, left the team behind with other work.

The scale of the REPUVE's work involved geography as well. In Zacatecas, a state with an appreciable rural population spread over a large geographic area, ensuring that vehicles in rural areas were included in the program posed a particular challenge. "It's like with the license plates," Diego Avila told me. "We know that in Zacatecas there are a half million registered vehicles, but there aren't a half million vehicles. There's more. Some aren't plated. Others have American plates. But there are more than a half million vehicles, which means that not all of the vehicles in the state are taxed." When I inquired why or how people don't register their cars, Avila responded,

Where are these people? In the villages. Why? Because maybe they make only a trip or two to the city. In the towns, in the cities, it's a bit stricter, because there's more people watching. There are cameras. You can't get away with as much. Eventually you're going to come across a traffic cop who's not going to do you a favor. And they're going to stop you and bring your car to the tow yard because you don't have plates. But there are villages that are very small, that have one or two traffic cops at most. And then it's your buddy, your neighbor, your brother, or your father who's stopping you. And then it's just "go on your way" [and nothing happens]. There are a lot of vehicles like that.

Interestingly, the same close-knit, local political networks that Daniela Flores and Samuel Gallo complained prevented them from implementing the REPUVE from above are also seen to work against the program on the ground.

Describing the geographic challenge for Zacatecas, Ignacio Meza, the state official responsible for the REPUVE there, explained that "the problem with Zacatecas is that we have towns almost four hours from

d. In spoken Spanish, $b$ 's and $v$ 's are interchangeable and hard consonants at the end of Hispanicized foreign words are often dropped. This example is a reminder of how the unruly nature of language can complicate controlling human communication. 
here [the capital city]. For example, to the north is Concepción del Oro and Mazapil. They're small, but we have to provide them the service." So the state decided to employ mobile registration modules, housed in mobile trailers that "could be moved for a week or two, to have a fixed module there." But in electing mobile units over stationary ones, the necessary computer software had to be broadcast remotely via radio frequency. "At the time," said Meza, "I spoke with the data specialists, [explaining] that this was the model we were going to replicate in all of the principal towns. We were not going to be able to connect all of them with cables. The idea was to install these mobile modules. . . So we tried to replicate in Zacatecas how the connection would be there, via remote antennas." But frequently during my observations, the team registering vehicles experienced service disruptions that delayed the transmission of data from the registration site to the secretariat's database. When I asked Meza about these disruptions, he shared that the system specialists "said that these things are out of our hands. Maybe the telephone company, which administers the Internet connection, had an issue. Or maybe there was a problem of some sort. Someone hit a telephone pole. Or someone was digging and cut the fiber-optic cables."

\subsubsection{Technical Glitches}

The difficulties experienced by REPUVE Zacatecas in providing ambulatory service touches on another challenge facing the Mexican government's attempts to enroll surveillance technologies in the fight against crime: technological malfunction. Prohesion as a form of governance depends on the performative capacities of surveillance and other information technologies. When those technological artifacts cannot do what they are intended to do, the programs themselves are at risk.

Technological malfunction can be caused by a struck telephone pole or an unknowing utility worker who cuts a ground cable. Or it can result from other dangers lurking in both built and natural environments. Sucaro, for instance, the car importer, had to figure out how to tag vehicles coming off ships from Asia en route to their dealerships. "Distinct from other companies that have their own yards," Agustín Sandoval and Felipe Ibarra explained to me, "we have a process where on the ship that arrives to port, some of the cars go to a yard as inventory, but the majority have already been sold. So they go directly to the dealers. The challenge was to set up the application of the chips without affecting the commercial process. The solution that we had to 
come up with was to do everything at the port." But the company soon encountered problems, according to Sandoval:

The first big problem we had there was that the printer bar codes from the plant arrived pixelated. The print was a bit blurry. And when there is a lot of sun, which is normal, the infrared couldn't read [the bar codes]. We struggled with this. So we would begin the work very early, at eight in the morning, and it [the tag] could be read because there wasn't so much sun. But when the sun really started, we would start to have problems. To find out what was going on, we had to get in touch with the producer of the handheld readers directly. And they told us the handheld readers had to operate with thermal paper. Without it, and with extreme solar radiation, it wouldn't read.

If the technological artifacts on which the Mexican state's prohesive plans depended could fail at inopportune times, the things they were meant to monitor could present challenges of their own. For the REPUVE, for instance, variability in vehicle identification standards has complicated vehicle registrations. There is no single standard for assigning VINs. The seventeen-digit number identifying the car's manufacturer and characteristics, including model year, was adopted in many parts of the world in the early I980s, though the United States and Canada employ a slightly different protocol. In Mexico, as Rodrigo Domínguez with REPUVE Sonora told me, "the international norm, or the norm from America, was applied . . beginning in 1997. All of the manufacturers-or let me put that in quotation marks-most of the manufacturers have followed that. And this has been the norm really since 1997." Vehicles produced in Mexico before that time, however, present particular difficulties. "Nissans and Volkswagens from '95, '96, '97, as well as Chevys from '94," Domínguez elaborated, "they can't be put into the Public Registry of Vehicles for now. The system doesn't allow the registration of their serial numbers because of a production problem in those vehicles. The REPUVE system detected duplicate serial numbers in those brands, which caused the service to be suspended."

The differing norms for identifying cars complicates vehicle inspection as well. To verify a vehicle's identity, REPUVE inspectors must document three matching instances of the VIN. The first instance is routinely located on the vehicle dashboard. The second is commonly located on the car body, under the hood and below the windshield wipers. A third is usually found on the doorjamb. If the VIN is absent from any of these three locations for whatever reason, the next place to look is on the chassis. And locating that VIN can be problematic, as it is not 
intended to be easily found. Ignacio Meza with REPUVE Zacatecas told me, "It took us fifteen days to be trained with all the makes and models. In addition, they [the technicians] have a logbook where they note the make, model, and where the secret numbers are located." This logbook was a point of pride among the inspectors, who approached this aspect of vehicular verification as a sort of riddle or problem to be solved.

Of course, each day presents its own challenges for inspectors, and a vehicle not previously encountered can always appear. "Just yesterday," Rodrigo Domínguez, the REPUVE Sonora site manager, told me,

a Nissan Tsuru came by that was completely different from what was on the bill of sale. What the bill of sale said was that it was a Ford Explorer. What happened is that the car had been hit, they recovered it, and they reassembled it with other pieces. So how am I going to validate it? I said to the guy, "Give me your documents, your bills, et cetera," and with that we were able to document that we had encountered a vehicle with a different serial number. In this case, the technician recorded the serial number from the doorjamb to register the vehicle. ... The vehicles can receive a chip as long as we normalize [these discrepancies]. But if nothing remains of a car other than the parts, or 50 percent of a vehicle remains, then it's the other 50 percent of the other vehicle that we would have to register.

If automobile idiosyncrasies can present challenges for their registration and inspection in the REPUVE program, so too can they complicate their regulation. "Another problem that came up, which was a big pain," explained Domínguez in Sonora, "was the fact that vehicles that have metallic particles [in their windshields] don't allow readings from the equipment. They estimate that around 3 percent of the 25 million vehicles in the country, around 750,000 , cannot have readings.... One of these is the Partner from Renault from 2007. It is going to be a pain for owners, unfortunately. We cannot put a chip on the windshield because it won't be read." Metallized windshields in certain makes and models are common. And while REPUVE administrators hoped that the number of vehicles affected would be less than 3 percent of the total

e. During my week at the REPUVE site, a Jeep Liberty arrived for its sticker. The team had never encountered the vehicle before and was having difficulty locating a third VIN. Being the son of a Jeep dealer, I decided to spend a not insignificant sum of Telcel credit to dial the family dealership and ask where the third number might be found. The dealership had the location for us in a matter of minutes, suggesting perhaps that greater coordination with automobile manufacturers or dealers could mitigate the challenges of locating VINs in the future. 
vehicle roll, in fact more than thirty makes and one hundred models have metallized windshields. ${ }^{60}$ Thus, the reading of REPUVE's RFID tags has been complicated by the materiality it is meant to control.

In addition to vehicles, paperwork can also present complications. Generally, drivers need to present five documents to register: a bill of sale from the purchase of the vehicle, a vehicle registration, a driver's license, a proof of residency, and an official form of identification. At times, people I spoke with who were registering their vehicles had difficulty gathering the necessary documents to obtain their tags. "I had to fight a lot for the documents they ask for," one woman told me in Sonora. "I fought. It was annoying because they said that the documents were fine. But afterward, they told me that they were insufficient and I made three appointments to come in. So I had to come in three times because of misunderstandings about my documentation. The last time they told me that I was missing this document and that. I was sick of it. Finally, I said, 'Hey, I'm not going to get anything else.' That was the last fight and it looks like it's OK now."

Some drivers with paperwork problems blamed themselves. "It was my fault," said another woman. "I didn't bring the required documents. So I had to make three trips. [Three?] Yeah, three, but they told me. They were very clear with me at the beginning in saying, 'You need this, that, and the other thing, the original bill of sale.' I didn't want to bring it because it's a bill of sale and I keep it safe. Now I brought it and everything is perfect."

But others were not so understanding. "It's incompetence. How do you say it?" complained one man I spoke with at the module in Sonora. "Negligence":

They have to verify the documents. I came yesterday to complete the transaction and they told me I lacked a document. I brought it today, and today they tell me that I am missing a notary on my bill of sale. This is a pain. Because yesterday they should have told me, "You are missing a stamp. Come again tomorrow and have them stamp this." Now they tell me that they can't do the transaction for me because I have to bring in the notarized version. I asked them, "What is your job here?" She told me, "We don't stamp that." Fine, "But what is your job? Checking that you have all the documents and that the documents are in order. But you didn't do that." She started with, "Well, what happened is ... " "No! You didn't do it. If you told me yesterday that the document was missing a stamp, I would go today, or go yesterday, and have them put the stamp on the document. And today I'd come here and you would finish the transaction." Now I have to go to another office so they can put a stamp that they didn't put before. 
The REPUVE's diverse technical challenges discussed here, it must be noted, did not necessarily jeopardize the registration and inspection of vehicles. Sketchy network connections could eventually be reestablished. Someone low in the Plataforma México queue would eventually receive service. Erroneous data entries could be cleaned up. Rural areas outside the grasp of the law would eventually be reached. Malfunctioning equipment could always be diagnosed and fixed. Hidden VINs could, with persistence, be unearthed. And missing paperwork could eventually be supplied. But these challenges each led to delays that increased dissatisfaction with the program among drivers, sujetos obligados, and governmental actors who were choosing to stand "before the law" and participate.

\subsection{RETHINKING RESISTANCE; OR, HOW COLLECTIVE AGENCIES GIVE THE PROHESIVE STATE THE SLIP}

And so it was during 20I0-I I that the Mexican government found its plans to gain a firmer grip on mobile telephony, automobility, and personal identification floundering on the brink of failure. Individuals fearful of losing their privacy or entrusting their data to the state organized themselves in digital spaces to share strategies for evading the telephone registry. Car companies complied with new requirements to facilitate the automobile registry but launched a lawsuit and took to the media in an attempt to modify the REPUVE legislation. The federal agency that saw its mission threatened by the new national identity card worked the media to foster opposition to the card. State governments apprehensive about the costs and potential for success of the vehicle registry, meanwhile, either refused to apply tags to vehicles or suspended operations. And those states that did apply the tags found themselves, like the sujetos obligados in the private sector, facing technical challenges that complicated their attempt to comply with the law.

These difficulties experienced by the Mexican government can partly be explained, as this chapter has shown, using the conceptual repertoire that political scientists and sociolegal scholars have developed to study the state and law. Ordinary Mexicans opposed to the RENAUT organized themselves to "stand against the law." Their actions did not attempt to repeal the law or topple the Calderón administration. Rather, they, like the campesinos who refused to participate in Mexico's Agrarian Census following the Revolution, ${ }^{6 \mathrm{I}}$ attempted to evade the law either by refusing to register or by providing false information, individual actions that can be read as "weapons of the weak." The 
decidedly nonweak-multinational automobile corporations-by contrast felt that they could not risk being so bold or flippant in their position vis-à-vis the law. Not complying with the REPUVE risked state sanction, which could harm business operations more than complying with the law in the first place. Nevertheless, the new automobile registry did imply significant costs. Thus, the companies opted to challenge the program "through the law" by suing to have the law changed.

But these conceptualizations of resistance only go so far in explaining the difficulties facing the Calderón administration. Major challenges jeopardizing these programs came not only from individual citizens and incorporated businesses. In the case of the Citizen Identity Card, the main opposition originated from within the state itself, the Federal Electoral Institute. In the case of the automobile registry, the primary sources of defiance again arose from within the political system, the individual states or entidades federativas that refused to implement the program. In the case of the telephone registry, in addition to the ten thousand Calderóns, design failure was the major obstacle that left the government without a clear strategy for verifying the phone numbers of the 90 percent of mobile phone users who did register their data, whether earnestly or not. Thus, the trials and travails of the Mexican government in implementing its prohesive vision of governance suggest sites of conflict and contestation beyond those that have captured the attention of scholars in the past.

With regard to the state-based obstacles encountered by the CEDI and REPUVE, it is interesting to consider, if we take a long enough timeline, that the Federal Electoral Institute's voter card, or even the federalist composition of political power in Mexico, embodies the substance of earlier efforts to manage the collective agencies of society. As noted in the first chapter, the IFE is a body created by Mexican authorities following the popular outrage over the 1988 presidential election, the one in which IBM's computers crashed as it appeared that the opposition candidate, Cuauhtémoc Cárdenas, was heading to victory. And the voter card and the biometrics it contains took shape over the twentieth century in order to govern personal identity in a manner conducive to democratic governance in Mexico. The federalist system, meanwhile, enshrined in Mexico's Constitution following the bloody civil conflict of the Revolution, is a solution to the challenges of constructing a single, unified political system for a geographic space defined by regional rivalries since pre-Columbian times. ${ }^{62}$ In this sense, the challenges encountered by the Calderón administration in enacting its new 
strategies for capturing the collective agencies of Mexican society are concentrated in the old infrastructure, bodies, practices, and agreements that had been developed to capture the collective agencies of Mexico in the past. This is, in essence, "law against itself."

A similar dynamic can be detected in the technical challenges faced by the REPUVE and RENAUT programs. With cars manufactured before I997, when Mexico adopted an international standard for identifying vehicles, the REPUVE comes up against an older way of ordering vehicles that does not lend itself to the new strategy. And these vehicles are able, then, to escape the grip of the new registry.

But with automobiles, a challenge beyond older modes of ordering is their materiality. Vehicles resist government efforts to be controlled. Metallized windshields provide a material barrier that insulates cars from being read. The absence of windshields or the reduced size of windshields on motorcycles, meanwhile, has prevented them from being tagged by the REPUVE program. Reassembled cars, a common phenomenon in Mexico and other poorer countries, ${ }^{63}$ a technological embodiment of mestizaje (racial mixing), befuddle official ways of identifying vehicles to guarantee "legal certainty."

Of course, the material objects complicating REPUVE's operation have not just been automobiles. Computers crash, their operability stretched by the need to communicate remotely in the rural expanses of Mexico. Bar codes pixelate when printed on nonthermal paper, hiding the information they were meant to convey when the sun intensifies. And other technological challenges-disruptions in mobile telephony for Telcel subscribers or unresponsive webpages-are an ever-present reality in the material world.

These examples invite a reconceptualization of resistance that takes account of such forces. But how would one do that? A sensible place to start would be science and technology studies (STS) that highlight how nonhuman things-sea scallops in Saint-Brieuc Bay, ${ }^{64}$ the anthrax ravaging cattle in the French countryside during the nineteenth century, ${ }^{65}$ the bubble chamber built by Donald Glaser to detect subatomic particles " - "resist" the efforts of scientists and engineers to bring them into their plans for ordering the world. This "material agency" is at the heart of scientific and technological failure, just as scientists' and engineers' ability to "capture" it lies at the heart of its progress. ${ }^{67}$

These concepts can be brought to bear on surveillance and the state. Like scallops, anthrax, and bubble chambers, the material agency of windshields, bar codes, and computers represent points of contestation 
that challenge the power and operation of state surveillance programs in Mexico. But we need not stop with material objects. Rather, the nonhuman agency working against the CEDI and REPUVE includes certain arrangements of political life or ways of ordering society-the "co-productions" 68 or "assemblages" of the state-that are inherited from authorities' past attempts to capture the collective agencies of society.

To formalize this train of thought, we need not limit ourselves to defining resistance, as James Scott does, as "any act(s) by member(s) of a subordinate class that is or are intended either to mitigate or deny claims made on that class by superordinate classes or to advance its own claims vis-à-vis those subordinate classes." ${ }^{70}$ This definition restricts itself to human actors of a subordinate class, overlooking other force relations in society that can count more centrally in the fate and outcomes of governmental projects and define the contours and limits of power. Instead, we might better define resistance as "any force, whether human or not, that has the effect of obstructing the intended plans and intentions or established relational patterns of authorities."

This definitional change provides both a fuller understanding of the experiences of surveillance technologies in Mexico's War on Crime and a different way of studying surveillance and state power going forward. For one, it shifts analysis from "members of a subordinate class" to "the plans and established patterns of authority." That is, it moves analytical focus from the weak to the strong. The rationale for privileging the actions of the poor is clear for a field of research interested in contesting social inequalities. "The celebration of some forms of resistance contains implicit commitments to social justice and equality," Sally Engle Merry writes. Thus, "it would be more honest to acknowledge where we stand and join in the search for a more just world." ${ }^{7 \mathrm{I}}$ Practically, however, we can ask whether focusing on the weak leaves the powerful out of our immediate focus. To understand power, it seems right to place the designs of the powerful at the forefront of analysis.

Second, the new definition shifts analysis of resistance from relativistic meanings (the "intentions" of individual members of subordinate classes) to general outcomes ("the effect of obstructing plans" that affect the social environment through which human activity is conducted). The reasons for wanting to privilege the intentions of ordinary people are again understandable. The disappointments of collective action following the I960s and I970s in the United States, Europe, and Latin America owed in good measure to social movements' disregard for the views, values, and interests of some members, usually those who were not male 
or European, which limited the movements' appeal and democratic potential. ${ }^{72}$ Too often, the means were ignored for the ends. Nevertheless, attending to the intentions of actors also draws our gaze away from the more objective, material outcomes of action that, as STS has shown, must be taken into account to understand social action and outcomes.

If the preceding two points, by moving away from perspectives that prioritize the meaning making of the less privileged, seem conservative, it bears saying that reconceptualizing resistance in this way can also expand what is considered the field of political dispute. By limiting ourselves to a definition of resistance as "intentional action," " our analysis can overlook those actions that might be unintentional but still effective in countering the plans of authorities. I have in mind here some of the tweets against Mexico's phone registry that started this chapter. A tweet such as "They can take away our cell phone numbers but they cant [sic] take away our freeeeeeeeeedoooooooooom" or "Did you know the \#RENAUT plans to include your fingerprints in a second stage?" can only with difficulty be read as intentional actions in opposition to the government. The first is a stab at humor, a play on Mel Gibson's iconic rallying cry as Braveheart, and the second could merely be informational, telling readers what will follow with the registry. However, these comments, something akin to gossip or chatting, can diminish the legitimacy of the registry and serve to counter its power. Similarly, simply purchasing a vehicle that turns out to have a metallized windshield or reassembled parts can unknowingly obstruct the advance of a governmental program like the vehicle registry.

These actions cannot be described as democratically expansive, but they do encourage us to imagine a wider space of political contestation than might otherwise be imagined. Indeed, if collective agency in society can be seen as distributed across a collection of human and nonhuman actors, including governmental state structures that are "co-produced" in the process of regulating those agencies, it stands to reason that each link in that distribution can serve as a site of resistance. In Mexico's War on Crime, as the federal government has sought to reorder mobile telephony, automobility, and personal identification by "making things stick," these agencies have proven resistant to change at points all along their distributions, from the intentions of ordinary Mexicans to the pixels of bar codes.

f. Jocelyn Hollander and Rachel Einwohner note that the common threads between the disparate uses of "resistance" in the social sciences are "a sense of action" and "a sense of opposition" (Hollander and Einwohner, "Conceptualizing Resistance," 538). 